\title{
The Effect of Core Training on Posture
}

\section{Sibel Karacaoğlu}

\author{
Pamukkale University School of Physical Education and Sport /Denizli/Turkey
}

\author{
Doç. Dr. Fatma Çelik Kayapinar
}

\author{
Mehmet Akif Ersoy University School of Physical Education and Sport/Burdur/Turkey
}

sguven@pau.edu.tr

\section{Doi:10.5901/ajis.2015.v4n1s2p221}

\begin{abstract}
The aim of the study is to investigate the effect of sample core training program on the posture of male volleyball players. The study was conducted with a total of 21 male volleyball players aged between 19 and 24 who are willing to participate in the study and have no health problem and these participants were selected randomly. 11 of them were determined as the treatment group while the other 10 was the control group of the study. A core training program was applied to the treatment group three days a week for 10 weeks. On the other hand, the control group did not get any training but continued its daily style. In the data gathering process, New York Posture Analysis (NYPA) evaluation form was used. The variables assessed before and after the application for both of the groups were head, neck, central shoulder, shoulders, chest, upper back, lower back, spine, trunk, belly, hip, foot and foot soles. For the analysis of the data gathered through NYPA, in order to compare preand post test values of treatment and control groups, independent $T$ test was used while for the comparison of pre- and post test values of the treatment group, and for the comparison of pre- and post test values of the control group, dependent $T$ test was used. According to the statistical analysis of data, when pre- and post test dependent $T$ test results of posture analysis in the treatment group were compared, a statistical difference was found between the values of neck, chest, central shoulder and lower back. The results of our study suggest that core training program contributes to the posture improvement in volleyball players positively.
\end{abstract}

Keywords: Volleyball, core training, posture

\section{Introduction}

Identifying the physical fitness level of the sportsmen and the physical development caused by regular sports trainings carried out to reach specific aims is of critical importance. This is mainly because body structure and qualities are developed in trainings (Çimen and Günay, 1996). Posture is the way in which each part of the body is placed into the segments adjacent to itself and also in the most appropriate position considering the entire body. Posture is also defined as the combinations of positions the joints have with each movement of body (Tunç, 2008). When there is no asymmetrical situation or deformity in one's body, then the posture is normal. Desirable posture can be defined as " the posture where joints experience the least pressure and so use minimum energy (Can, 2008).

There is a great number of mechanisms to maintain posture. For the maintenance of posture, lots of structures such as spinal cord, brain stem and cerebral cortex are included. Posture and equilibrium is maintained through the signs coming from vestibular organ in inner ear and receptor through reflex way. These centres contributing to the maintenance of posture and equilibrium not only produce posture and equilibrium but also deal with the starting and controlling of the actions (Günay, Tamer and Cicioğlu, 2006).

Posture Analysis can be conducted in three dimensions as anterior, lateral and lateral. In the criteria of posture, standard (good) and bad postures are taken into account (Karakuş and Kılınç, 2006). The aim of posture analysis is to determine the present postural deviations in people and to provide suitable exercises regarding this, and also to analyse the possible changes likely to happen in the future (Çelik, 2007).

Elite sportsmen, in order to adjust the posture according to the requirements of their branches, use sensory knowledge predominantly (Tetik, Koç, Atar and Koç ,2013). Each sports branch develops its own postural adaptations specific to itself (Atılgan, Akın, Alpkaya and Pınar, 2012). During the performing of technical attempts in volleyball, a dynamic sports branch, it is necessary for the players to protect their posture. By producing the appropriate equilibrium, 
all body movements such as serve, block and attack skills are assured to take place. That these skills are performed successfully depends on the ability of the player to control postural sway. It is seen that volleyball players have more body stability and different automatic postural control modes (Şimşek and Ertan, 2011).

The part of the body that is called core is the place beyond one's abdominal muscles, that is, lower- upper abdominal muscle. The location of core includes seratus located just next to upper abdominal muscle and obliques located next to lower abdominal muscle, and at the back it resides in the the part from the waist to neck including the muscle group enabling our skeleton to have an appropriate posture. The importance of strengthening the core is not just because of the sporting endurance but because it enables a proper posture (http: //blog. milliyet. com. tr/)

Core training includes exercises that train the muscles controlling and stabilising belly, waist and hip actions. All of these muscles work together so as to balance the body during the actions. The efficient transfer of the strength rising through the action from leg to trunk or from trunk to leg is possible with the increase in strength of these coordinating muscles. The method of core training differs from weight training in terms of application and also it is carried out so that strength is saved during the process of improving the performance and rehabilitation (Savaş, 2013).

The effect of core training on the endurance, flexibility and balance development of the muscles related to posture in sedentary women was analysed and it is found out that there is a significant improvement in the endurance and strength of lower back and abdominal muscles after the exercise program (Sekendiz et al. 2010). However, up to now, the effect of core training on posture in sportsmen has not been studied yet. The aim of this study is to investigate the effect of core training program on the postures of male volleyball players.

\section{Methods}

In the design of the study, quasi-experimental model with pre-post test control group was used. The participants of the study consisted of a total of 21 male licensed volleyball players aged between 19 and 24 in Denizli. The treatment and the control groups were randomly chosen and out of 21 volunteer students, 11 of them were determined as the treatment group while the other 10 was the control group of the study. The researcher gave the participants some general information about the study and emphasized that voluntariness is a key for the study.

The posture of the participants was analysed through New York Posture Analysis (NYPA) evaluation form. The measurements for the posture analysis was conducted by the first writer. The posture of the participants in both of the groups were evaluated in the beginning of the study and 10 weeks later. A core training program was applied to the treatment group three days a week for 10 weeks. On the other hand, the control group did not get any training.

New York Posture Analysis Method: Possible Postural changes likely to happen in 13 different body segments were observed and graded. According to this, it is graded as five (5) for normal posture; three (3) for moderate postural problems; and one (1) for severe postural problems. The maximum point obtained in the scale can be 65 while the minimum is 13. Scores in the range of >=45 are defined as "very good", 40-44 "good", 30-39 "middle", 20-29 "weak", and $<=19$ as bad (Çağıran, 2010).

Core Training Program: A core training program was applied three days a week (Monday, Wednesday, Friday) for 10 weeks with a total of 30 sessions. The program consists of warm-up, core exercises and cooling. In the first 6 week of the program, intermediate level and in the last 4 weeks advanced level of core training is applied.

In order to compare pre- and post test values of intergroup ( between treatment and control groups) independent T test was used, while dependent $\mathrm{T}$ test was used for the values within the group.

\section{Results}

Table 1: The results of Pre- test independent T test Posture Analysis Obtained through NYPA

\begin{tabular}{llllcccc}
\hline \multicolumn{1}{c}{ Variable } & Group & $\mathrm{N}$ & Mean & Standard Deviation & Degrees of Freedom & $\mathrm{t}$ & $\mathrm{P}$ \\
\hline Head & Treatment & 11 & 4,63 & 0,80 & 19 & \multirow{2}{*}{0,101} & \multirow{2}{*}{0,921} \\
\multirow{3}{*}{ Shoulder } & Control & 10 & 4,60 & 0,84 & & & \\
\multirow{2}{*}{ Spine } & Treatment & 11 & 4,09 & 1,04 & 19 & 0,641 & 0,529 \\
& Control & 10 & 3,80 & 1,03 & & & \\
Hip & Treatment & 11 & 4,81 & 0,60 & 19 & 1,202 & 0,244 \\
& Control & 10 & 4,40 & 0,96 & & & \\
& Treatment & 11 & 4,81 & 0,60 & 19 & 0,067 & 0,947 \\
\hline
\end{tabular}




\begin{tabular}{|c|c|c|c|c|c|c|c|}
\hline \multirow[t]{2}{*}{ Foot } & Treatment & 11 & 5,00 & 0,00 & \multirow{2}{*}{\multicolumn{3}{|c|}{19}} \\
\hline & Control & 10 & 5,00 &, $00000^{a}$ & & & \\
\hline \multirow[t]{2}{*}{ Sole } & Treatment & 11 & 4,63 & 0,80 & \multirow[t]{2}{*}{19} & \multirow[t]{2}{*}{0,101} & \multirow[t]{2}{*}{0,921} \\
\hline & $\begin{array}{l}\text { Control } \\
\text { Treatment }\end{array}$ & $\begin{array}{l}10 \\
11\end{array}$ & $\begin{array}{l}4,60 \\
372\end{array}$ & $\begin{array}{l}0,84 \\
100\end{array}$ & & & \\
\hline Neck & Control & $\begin{array}{l}11 \\
10\end{array}$ & 3,60 & $\begin{array}{l}1,60 \\
1,64\end{array}$ & 19 & 0,216 & 0,831 \\
\hline \multirow[t]{2}{*}{ Chest } & Treatment & 11 & 4,27 & 1,00 & \multirow{2}{*}{19} & \multirow{2}{*}{$-0,802$} & \multirow{2}{*}{0,433} \\
\hline & Control & 10 & 4,60 & 0,84 & & & \\
\hline \multirow[t]{2}{*}{ Central shoulder } & Treatment & 11 & 3,72 & 1,00 & \multirow{2}{*}{19} & \multirow{2}{*}{0,246} & \multirow{2}{*}{0,808} \\
\hline & Control & 10 & 3,60 & 1,34 & & & \\
\hline \multirow{2}{*}{ Upperback } & Treatment & 11 & 3,72 & 1,00 & \multirow{2}{*}{19} & \multirow{2}{*}{0,246} & \multirow{2}{*}{0,808} \\
\hline & Control & 10 & 3,60 & 1,34 & & & \\
\hline \multirow[t]{2}{*}{ Trunk } & Treatment & 11 & 4,09 & 1,04 & \multirow{2}{*}{19} & \multirow{2}{*}{0,544} & \multirow{2}{*}{0,593} \\
\hline & Control & 10 & 3,80 & 1,39 & & & \\
\hline \multirow[t]{2}{*}{ Belly } & Treatment & 11 & 4,81 & 0,60 & \multirow{2}{*}{19} & \multirow{2}{*}{0,687} & \multirow{2}{*}{0,500} \\
\hline & Control & 10 & 4,60 & 0,84 & & & \\
\hline \multirow[t]{2}{*}{ Lowerback } & Treatment & 11 & 3,72 & 1,00 & \multirow{2}{*}{19} & \multirow{2}{*}{1,127} & \multirow{2}{*}{0,274} \\
\hline & Control & 10 & 3,20 & 1,13 & & & \\
\hline \multirow[t]{2}{*}{ Total nypa score } & Treatment & 11 & 56,09 & 5,08 & \multirow{2}{*}{19} & 0,618 & 0,544 \\
\hline & Control & 10 & 54,20 & 8,65 & & 0,010 & \\
\hline
\end{tabular}

When the pre test results of the groups are compared, no significant difference is found in posture analysis scores $(p>0$. 05). This result indicates that postural conditions of the treatment and the control groups are similar in the beginning of the study.

Table 2: The results of Post test independent T test Posture Analysis Obtained through NYPA

\begin{tabular}{|c|c|c|c|c|c|c|c|}
\hline Variable & Group & $\mathrm{N}$ & Mean & Standard Deviation & Degrees of Freedom & $\mathrm{t}$ & $\mathrm{P}$ \\
\hline Head & Treatment & $\begin{array}{l}11 \\
10\end{array}$ & 5,00 & 0,00 & 19 & 1,577 & 0,131 \\
\hline Shoulder & $\begin{array}{l}\text { Treatment } \\
\text { Control }\end{array}$ & $\begin{array}{l}11 \\
10\end{array}$ & $\begin{array}{l}4,45 \\
3,80\end{array}$ & $\begin{array}{l}0,93 \\
1,03\end{array}$ & 19 & 1,525 & 0,144 \\
\hline Spine & $\begin{array}{l}\text { Treatment } \\
\text { Control }\end{array}$ & $\begin{array}{l}11 \\
10\end{array}$ & $\begin{array}{l}5,00 \\
4,40\end{array}$ & $\begin{array}{l}0,00 \\
0,96\end{array}$ & 19 & 2,065 & 0,053 \\
\hline Hip & $\begin{array}{l}\text { Treatment } \\
\text { Control }\end{array}$ & $\begin{array}{l}11 \\
10\end{array}$ & $\begin{array}{l}5,00 \\
4,80\end{array}$ & $\begin{array}{l}0,00 \\
0,63\end{array}$ & 19 & 1,052 & 0,306 \\
\hline Foot & $\begin{array}{l}\text { Treatment } \\
\text { Control }\end{array}$ & $\begin{array}{l}11 \\
10\end{array}$ & $\begin{array}{l}5,00 \\
5,00\end{array}$ & $\begin{array}{l}0,00 \\
0,00\end{array}$ & 19 & & \\
\hline Sole & $\begin{array}{l}\text { Treatment } \\
\text { Control }\end{array}$ & $\begin{array}{l}11 \\
10\end{array}$ & $\begin{array}{l}4,81 \\
4,60\end{array}$ & $\begin{array}{l}0,60 \\
0,84\end{array}$ & 19 & 0,687 & 0,500 \\
\hline Neck & $\begin{array}{l}\text { Treatment } \\
\text { Control }\end{array}$ & & & & 19 & 1,273 & 0,219 \\
\hline Chest & $\begin{array}{l}\text { Treatment } \\
\text { Control }\end{array}$ & $\begin{array}{l}11 \\
10\end{array}$ & $\begin{array}{l}5,00 \\
4,60\end{array}$ & $\begin{array}{l}0,00 \\
0,84\end{array}$ & 19 & 1,577 & 0,131 \\
\hline Central shoulder & $\begin{array}{l}\text { Treatment } \\
\text { Control }\end{array}$ & $\begin{array}{l}11 \\
10\end{array}$ & $\begin{array}{l}4,63 \\
3,60\end{array}$ & $\begin{array}{l}0,80 \\
1,34\end{array}$ & 19 & 2,158 & 0,044 \\
\hline Upperbcak & $\begin{array}{l}\text { Treatment } \\
\text { Control }\end{array}$ & $\begin{array}{l}11 \\
10\end{array}$ & $\begin{array}{l}4,09 \\
3,20\end{array}$ & $\begin{array}{l}1,04 \\
1,13\end{array}$ & 19 & 1,873 & 0,076 \\
\hline Trunk & $\begin{array}{l}\text { Treatment } \\
\text { Control }\end{array}$ & $\begin{array}{l}11 \\
10\end{array}$ & $\begin{array}{l}4,45 \\
3,20\end{array}$ & $\begin{array}{l}0,93 \\
1,13\end{array}$ & 19 & 2,776 & 0,012 \\
\hline Belly & $\begin{array}{l}\text { Treatment } \\
\text { Control }\end{array}$ & $\begin{array}{l}11 \\
10\end{array}$ & $\begin{array}{l}4,81 \\
4,60\end{array}$ & $\begin{array}{l}0,60 \\
0,84\end{array}$ & 19 & 0,687 & 0,500 \\
\hline Lowerback & $\begin{array}{l}\text { Treatment } \\
\text { Control }\end{array}$ & $\begin{array}{l}11 \\
10\end{array}$ & $\begin{array}{l}4,45 \\
3,00\end{array}$ & $\begin{array}{l}0,93 \\
0,94\end{array}$ & 19 & 3,548 & 0,002 \\
\hline Total NYPA Score & $\begin{array}{l}\text { Treatment } \\
\text { Control }\end{array}$ & $\begin{array}{l}11 \\
10\end{array}$ & $\begin{array}{l}61,18 \\
53,20\end{array}$ & $\begin{array}{l}3,73 \\
7,68\end{array}$ & 19 & 3,073 & 0,006 \\
\hline
\end{tabular}

NYPA: New York Posture Analysis 
It is found out that there is statistically significant difference in the post test results of central shoulder, trunk, lower back and posture total scores for the benefit of the treatment group $(p<0.05)$. No significant relationship is found between the other variables ( $p>0.05)$. It can be inferred that the core training program contributes to the improvement of the posture positively.

Table 3: The Results of Dependent T test Posture Analysis of the Treatment Group Obtained through NYPA

\begin{tabular}{|c|c|c|c|c|c|c|c|}
\hline Variable & Test & $\mathrm{N}$ & Mean & Standard Deviation & Degrees of Freedom & $\mathrm{t}$ & $P$ \\
\hline Head & $\begin{array}{l}\text { Pre } \\
\text { Post }\end{array}$ & 11 & $\begin{array}{l}4,63 \\
5,00\end{array}$ & $\begin{array}{l}0,80 \\
0,00\end{array}$ & 10 & $-1,491$ & 0,167 \\
\hline Shoulder & $\begin{array}{l}\text { Pre } \\
\text { Post }\end{array}$ & 11 & $\begin{array}{l}4,09 \\
4,45\end{array}$ & $\begin{array}{l}1,04 \\
0,93\end{array}$ & 10 & $-1,491$ & 0,167 \\
\hline Spine & $\begin{array}{l}\text { Pre } \\
\text { Post }\end{array}$ & 11 & $\begin{array}{l}4,81 \\
5,00\end{array}$ & $\begin{array}{l}0,60 \\
0,00\end{array}$ & 10 & $-1,000$ & 0,341 \\
\hline Hip & $\begin{array}{l}\text { Pre } \\
\text { Post }\end{array}$ & 11 & $\begin{array}{l}4,81 \\
5,00\end{array}$ & $\begin{array}{l}0,60 \\
0,00\end{array}$ & 10 & $-1,000$ & 0,341 \\
\hline Foot & $\begin{array}{l}\text { Pre } \\
\text { Post }\end{array}$ & 11 & $\begin{array}{l}5,00 \\
5,00\end{array}$ & $\begin{array}{l}0,00 \\
0,00\end{array}$ & 10 & & \\
\hline Sole & $\begin{array}{l}\text { Pre } \\
\text { Post }\end{array}$ & 11 & $\begin{array}{l}4,63 \\
4,81\end{array}$ & $\begin{array}{l}0,80 \\
0,60\end{array}$ & 10 & $-1,000$ & 0,341 \\
\hline Neck & $\begin{array}{l}\text { Pre } \\
\text { Post }\end{array}$ & 11 & $\begin{array}{l}3,72 \\
4,45\end{array}$ & $\begin{array}{l}1,00 \\
0,93\end{array}$ & 10 & $-2,390$ & 0,038 \\
\hline Chest & $\begin{array}{l}\text { Pre } \\
\text { Post }\end{array}$ & 11 & $\begin{array}{l}4,27 \\
5,00\end{array}$ & $\begin{array}{l}1,00 \\
0,00\end{array}$ & 10 & $-2,390$ & 0,038 \\
\hline Central shoulder & $\begin{array}{l}\text { Pre } \\
\text { Post }\end{array}$ & 11 & $\begin{array}{l}3,72 \\
4,63\end{array}$ & $\begin{array}{l}1,00 \\
0,80\end{array}$ & 10 & $-2,887$ & 0,016 \\
\hline Upperback & $\begin{array}{l}\text { Pre } \\
\text { Post }\end{array}$ & 11 & $\begin{array}{l}3,72 \\
4,09\end{array}$ & $\begin{array}{l}1,00 \\
1,04\end{array}$ & 10 & $-1,491$ & 0,167 \\
\hline Trunk & $\begin{array}{l}\text { Pre } \\
\text { Post }\end{array}$ & 11 & $\begin{array}{l}4,09 \\
4,45\end{array}$ & $\begin{array}{l}1,04 \\
0,93\end{array}$ & 10 & $-1,491$ & 0,167 \\
\hline Belly & $\begin{array}{l}\text { Pre } \\
\text { Post }\end{array}$ & 11 & $\begin{array}{l}4,81 \\
4,81\end{array}$ & $\begin{array}{l}0,60 \\
0,60\end{array}$ & 10 & & \\
\hline Lowerback & $\begin{array}{l}\text { Pre } \\
\text { Post }\end{array}$ & 11 & $\begin{array}{l}3,72 \\
4,45\end{array}$ & $\begin{array}{l}1,00 \\
0,93\end{array}$ & 10 & $-2,390$ & 0,038 \\
\hline Total NYPA Score & $\begin{array}{l}\text { Pre } \\
\text { Post }\end{array}$ & 11 & $\begin{array}{l}56,09 \\
61,18\end{array}$ & $\begin{array}{l}5,08 \\
3,73\end{array}$ & 10 & $-6,169$ & 0,000 \\
\hline
\end{tabular}

NYPA: New York Posture Analysis

When the results of pre and post test posture analysis of the treatment group are compared, a statistically significant difference is found between the values of neck, chest, central shoulder and lower back $(p<0.05)$. Therefore, it can be suggested that the applied core training program contributed to the posture improvement of trunk and shoulder part.

Table 4: The Results of Dependent T test Posture Analysis of the Control Group Obtained through NYPA

\begin{tabular}{|c|c|c|c|c|c|c|c|}
\hline Variable & Test & $\mathrm{N}$ & Mean & Standard Deviation & Degrees of Freedom & $\mathrm{t}$ & $P$ \\
\hline Head & $\begin{array}{l}\text { Pre } \\
\text { Post }\end{array}$ & 10 & $\begin{array}{l}4,60 \\
4,60\end{array}$ & $\begin{array}{l}0,84 \\
0,84\end{array}$ & 9 & & \\
\hline Shoulder & $\begin{array}{l}\text { Pre } \\
\text { Post }\end{array}$ & 10 & $\begin{array}{l}3,80 \\
3,80\end{array}$ & $\begin{array}{l}1,03 \\
1,03\end{array}$ & 9 & & \\
\hline Spine & $\begin{array}{l}\text { Pre } \\
\text { Post }\end{array}$ & 10 & $\begin{array}{l}4,40 \\
4,40\end{array}$ & $\begin{array}{l}0,96 \\
0,96\end{array}$ & 9 & & \\
\hline Hip & $\begin{array}{l}\text { Pre } \\
\text { Post }\end{array}$ & 10 & $\begin{array}{l}4,80 \\
4,80\end{array}$ & $\begin{array}{l}0,63 \\
0,63\end{array}$ & 9 & & \\
\hline Foot & $\begin{array}{l}\text { Pre } \\
\text { Post }\end{array}$ & 10 & $\begin{array}{l}5,00 \\
5,00\end{array}$ & $\begin{array}{l}0,00 \\
0,00\end{array}$ & 9 & & \\
\hline Sole & $\begin{array}{l}\text { Pre } \\
\text { Post }\end{array}$ & 10 & $\begin{array}{l}4,60 \\
4,60\end{array}$ & $\begin{array}{l}0,84 \\
0,84\end{array}$ & 9 & & \\
\hline Neck & Pre & 10 & 3,60 & 1,64 & 9 & $-0,557$ & 0,591 \\
\hline
\end{tabular}




\begin{tabular}{|c|c|c|c|c|c|c|c|}
\hline & Post & & 3,80 & 1,39 & & & \\
\hline \multirow[t]{2}{*}{ Chest } & Pre & & 4,60 & 0,84 & \multirow{2}{*}{\multicolumn{3}{|c|}{9}} \\
\hline & Post & 10 & 4,60 & 0,84 & & & \\
\hline \multirow[t]{2}{*}{ Central shoulder } & Pre & 10 & 3,60 & 1,34 & \multirow{2}{*}{9} & \multirow{2}{*}{0,000} & \multirow{2}{*}{1,000} \\
\hline & Post & 10 & 3,60 & 1,34 & & & \\
\hline \multirow[t]{2}{*}{ Upperback } & Pre & & 3,60 & 1,34 & \multirow{2}{*}{9} & \multirow{2}{*}{1,500} & \multirow{2}{*}{0,168} \\
\hline & Post & 10 & 3,20 & 1,13 & & & \\
\hline \multirow[t]{2}{*}{ Trunk } & Pre & & 3,80 & 1,39 & \multirow{2}{*}{9} & \multirow{2}{*}{1,964} & \multirow{2}{*}{0,081} \\
\hline & Post & 10 & 3,20 & 1,13 & & & \\
\hline \multirow[t]{2}{*}{ Belly } & Pre & 10 & 4,60 & 0,84 & \multirow{2}{*}{9} & & \\
\hline & Post & 10 & 4,60 & 0,84 & & & \\
\hline \multirow[t]{2}{*}{ Lowerback } & Pre & & 3,20 & 1,13 & \multirow{2}{*}{9} & \multirow{2}{*}{1,000} & \multirow{2}{*}{0,343} \\
\hline & Post & 10 & 3,00 & 0,94 & & & \\
\hline \multirow[t]{2}{*}{ Total NYPA Score } & Pre & & 54,20 & 8,65 & \multirow{2}{*}{9} & \multirow{2}{*}{1,168} & \multirow{2}{*}{0,273} \\
\hline & Post & 10 & 53,20 & 7,68 & & & \\
\hline
\end{tabular}

When the results of pre and post test posture analysis of the control group are compared, no statistically significant difference is found $(p>0.05)$.

\section{Discussion}

In our study, we tried to investigate the effect of core training program on the postures of male volleyball players and found that this program developed the posture of the sportsmen positively.

The body parts where postural improvements were specifically observed are central shoulder, trunk and lower back. This suggests the idea that core training affects the endurance and the strength of trunk muscles.

An earlier study also supports our view. Sekendiz et al. (2010) investigated the endurance, flexibility and balance development of the muscles that core training affects in terms of posture. After an 8 week of exercise program applied to 21 sedentary women, they stated that there was a good improvement in the endurance and the strength of lower back and abdominal muscles.

In the control group, where there is no training program applied, any postural improvements are not observed. The fact that they haven't done any exercises during the applied training program even though they were sportsmen may explain that there is no improvement on the variables tested. It can be said that daily life has no effect on postural conditions.

\section{Conclusion and Suggestions}

The results of our study suggest that core training program contributes to the posture improvement in volleyball players positively. Since it is a strength training model conducted with body weight, it can be easily carried out by individuals, team sportsmen and those doing sports by health reasons even if their economic conditions are poor and they do not have necessary physical conditions.

The improvement of posture is especially important for the volleyball sport, for the sports requiring a tall height and for tall people doing sports for health. It would be beneficial to include core training into training programs in order to fix postural problems. Core program can also be suggested to the sportsmen of other branches, where shoulder and trunk segments have postural sway.

Regarding the injuries in sports, postural problems and the lack of opportunities, trainers and sportsmen can be given the necessary educations so as to make core trainings more common.

Since core training focuses on the muscles in the body centre and strengthen these muscles and it is the combinations of the systematic exercises performed to improve and maintain posture, it is also beneficial to include it in almost every sports branch and in the programs of those doing sports.

\section{References}

Atılgan, O. E. , Akın, M. , Alpkaya, U. and Pınar, S. (2012). Elit bayan cimnastikçilerin denge aletindeki denge kayıpları ile denge parametreleri arasındaki ilişkinin incelenmesi. International Journal of Human Sciences, 9 (2). 
Can, B. (2008). Bayan voleybolcularda denge antrenmanlarının yorgunluk ortamında proprosepsiyon duyusuna etkisi. Yayımlanmamış doktora tezi, Ankara: Gazi Üniversitesi Sağlık Bilimleri Enstitüsü.

Çağıran, G. (2010). Ön diz ağrısı olan olgularda fiziksel aktivite, kardiyorespiratuar endurans, aktivite ve katılım sınırlııkları ve yaşam kalitesi arasındaki ilişki. Yüksek Lisans Tezi. Ankara: Başkent Üniversitesi Sağlık Bilimleri Enstitüsü.

Çelik, K. F. ( 2007). Örnek pilot çalışma programının okul öncesi çocuklarının antropometrik, postür ve fiziksel uygunluk düzeylerine olan etkisininn araştıııması. Yayımlanmamış doktora tezi, İstanbul: Marmara Üniversitesi Sağlık Bilimleri Enstütüsü.

Çimen, O. and Günay, M. (1996). Dairesel çabuk kuvvet antrenmanlarının 16-18 yaş grubu genç erkek masa tenisçilerin bazı motorik özelliklerine etkisi. Spor Bilimleri Dergisi, (3), 3 -11

Günay, M. , Tamer, K. and Cicioğlu, İ. ( 2006) Spor fizyolojisi ve performans ölçümü. Ankara.

Karakuş, S. and Kılınç, F. (2006). Postür ve sportif performans. Kastamonu Eğitim Dergisi, 14 (1), 309-322.

Savaş,S. (2013) Basketbolda core stabilizasyon ve thera band uygulamalarının performansa etkisi . Antrenman bilmi kongresi.

Sekendiz , B. , Cug, M. and Korkusuz, F. (2011). Effects of swiss-ball core strength training on strength, endurance, flexibility, and balance in sedentary women. J Strength Cond Res, 25 (1), 286.

Şimşek, D. and Ertan, H. (2011) ,Postural kontrol ve spor: spor branşlarına yönelik postural sensör-motor stratejiler ve postural salınım. Spormetre Beden Eğitimi ve Spor Bilimleri Dergisi, IX (3), 81-90

Tunç, P. (2008). Sağılk çalışanlarında kas iskelet sistemi bozuklukları ile ilgili yaşam kalitesini etkileyen faktörler. Yayımlanmamış yüksek, Ankara: Başkent Üniversitesi Sağlık Bilimleri Enstitüsü.

Tetik, S. , Koç, M. C. , Atar, Ö. and Koç, H. ( 2013). Basketbolcularda statik denge performansı ile oyun değer skalası arasındaki ilişkinin incelenmesi. Türkiye Kickboks Federasyonu Spor Bilimleri Dergisi, 6 (1) , 1309-1336

http: //blog.milliyet.com. tr/ 